\title{
A contemporary sense of existentialism
}

\author{
Darryl Wardle
}

Department of Philosophy, University of Pretoria, South Africa

wardle.darryl@gmail.com

\begin{abstract}
Philosophical existentialism has sought to understand the nature of human existence and the possible meaning(s) that might be made thereof. For the noteworthy existentialist Jean-Paul Sartre, the meaning of life cannot be said to subsist somewhere beyond the province of individual human existence, since meaning is born of a fundamental freedom which inheres in human consciousness. From a more contemporary poststructuralist philosophical perspective, however, one might argue that Sartre's individualist conception of existential meaning in Being and Nothingness remains fettered to an order of signification reliant upon a vestigial "metaphysics of presence", where the presence of the signified has simply been displaced from the transcendental domain to immanent human subjectivity. This is potentially problematic insofar as such an order of meaning qua signification is destined to suspend meaning at a perpetually deferred distance; and concomitantly, human existential meaning remains interminably frustrated. However, using the contemporary philosophical insights of Jean-Luc Nancy, it can be argued that a contemporary (re) conceptualisation of existentialist thought might allow existentialism to liberate itself from a ceaselessly suspended signification of meaning, specifically by arguing for a means-to-meaning(s) always already manifest(ing) between human beings oriented towards the contemporary world as a shared space of sense.
\end{abstract}

An earlier version of this paper was presented at the Annual Conference of the Philosophical Society of Southern Africa (PSSA) in Chintsa, South Africa, 18-20 January 2016. 
"More or less quietly, more or less clamorously, the question of meaning once again troubles the aging West, which believed itself to have overcome it."

- Jean-Luc Nancy (1997a: p. 9)

This paper is concerned with the philosophical question on the meaning(s) of life - what will hereafter be referred to as "existential meaning". Existential meaning is not to be equated merely with the semantic signification of logic and linguistics, but refers rather to that which might be thought to constitute a meaningful human existence; one which is considered worthwhile, valuable, purposeful, fulfilling, or in Aristotelean terms, a life of "eudaimonia". It is arguably through the philosophical discourse of existentialism that the question of existential meaning has received the most direct attention. ${ }^{1}$ For Jean-Paul Sartre (1905-1980), arguably the most well-known existentialist philosopher, and on whom the discourse at hand places its first focus, the meaning of life cannot be said to subsist somewhere beyond the province of individual human existence. For Sartre, existential meaning is born of human consciousness, constituted in a fundamental freedom and an ineluctable responsibility incumbent upon each individual to determine both the essence and the meaning of their being for, and by, themselves.

However, when evaluated from a contemporary philosophical perspective which accounts for the poststructuralist critique of meaning qua signification in the latter half of the twentieth century, Sartre's existentialist conception of meaning is rendered potentially problematic. Specifically, by considering the contemporary philosophy of Jean-Luc Nancy (1940-), which follows in the legacy of Jacques Derrida's (1930-2004) influential poststructuralist project of deconstruction, one might argue that Sartre's existentialist conception of meaning remains fettered to an outmoded order of signification reliant upon a vestigial "metaphysics of presence" (Derrida 2001: p. 354), ${ }^{2}$ where the presence of the signified has simply been displaced from the transcendental domain ${ }^{3}$ to immanent human subjectivity.

The investigation at hand seeks firstly to explicate Sartre's existentialist conception of meaning, as well as to demonstrate its philosophical and historical significance. Thereafter, the potential pitfalls of Sartrean philosophy on existential meaning will be revealed through the lens of Nancy's idiosyncratic form of poststructuralist thought. Finally, it will be argued that a new formulation of existentialism is needed for human existence in the world today, and a sketch for a possible groundwork of such a contemporary sense of existentialism will be provided by means of a succinct engagement with Nancy's apposite philosophical insights concerning the sense of the world and the possible meaning(s) of contemporary human existence.

\footnotetext{
${ }^{1}$ However, the investigation of existential meaning is by no means limited to the discourse of existentialism.

2 Derrida's conception of the "metaphysics of presence" is originally derived from Heidegger's "Destruktion" of metaphysics qua onto-theology in Being and Time, Introduction, §6. See also: Derrida 2004: pp. 284-290.

${ }^{3}$ Such as the Platonic Realm of the Forms, or a monotheistic conception of God residing in a supernal realm.
} 


\section{Sartrean Existentialism on Meaning}

"Who can doubt that the meaning of the sign was determined by him, and by him alone? ... He therefore bears the full responsibility for his interpretation of the sign."

- Jean-Paul Sartre (2007: p. 34)

In the mid-twentieth century, writing amidst the tragic maelstrom of World War II and the disenchantment that attended its harrowing eventualities, the famed existentialist philosopher Jean-Paul Sartre sought answers to the meaning of life that might allay the fury of our human fears, satisfy our most profound human desires, and bespeak a fundamental human freedom. Mired in a grim European political reality brought about by ideological absolutism, ${ }^{4}$ and fully cognisant of the rapidly waning strength of religious faith in the increasingly secular West, Sartre confronts the existential disillusionment of his age directly in his fictional, dramatic, and philosophical writings. Sartre's renowned work of phenomenological ontology in Being and Nothingness (1943), of which I can offer here only a rudimentary account, has become a veritable biblical text for scholars of existentialism, due both to its historical relevance, as well as the radical possibilities of meaning made possible through its robust argumentation.

However, Sartre's answers to the question on existential meaning are often interpreted as offering only the slightest sliver of a silver lining to a far darker cloud of consternation, entirely gravid with the gravity and excessive enormity of our human existence. Yet, much like human existence itself, Sartre's existentialism is neither wholly optimistic nor consistently nihilistic, but abundant with a rich ambiguity that situates itself between a radical and potentially hopeful freedom, and a deep despair which threatens to subsume humanity under a nihilistic pall. Sartre contends quite unequivocally that human existence is absurd (2003: p. 501) and "has no meaning a priori" (2007: p. 51). As an ardent atheist, Sartre asserts that there is no God nor any other external guarantee by means of which the absurdity of human existence might be allayed. This leads Sartre to posit the demanding and even somewhat daunting doctrine in Existentialism is a Humanism (1946) that humanity is henceforth abandoned to the immanent reserve of its own existential resources. Sartre (2003: p. 63) further expresses this thought in terms of a radical individualism of existential meaning as follows:

"I have to realize the meaning of the world and of my essence; I make my decision concerning them - without justification and without excuse".

In Being and Nothingness, Sartre offers a radical and robust account of the myriad vagaries and vicissitudes of conscious human experience, and explicates extensively on how human individuals render their worldly existence meaningful. Sartre's phenomenological account of

\footnotetext{
${ }^{4}$ Specifically, the secular socio-political ideology of NAZI Germany.
} 
human existence begins with the premise that human consciousness, or "being-for-itself" [êtrepour-soi], stands in a relation of dialectical negation to the world of non-conscious being, collectively designated as "being-in-itself" [être-en-soi]. Since human consciousness, as beingfor-itself, is dialectically opposed to the undifferentiated world of things, viz. being-in-itself, it is precisely not a thing; it is no-thing. The internal dialectical negation of undifferentiated reality ('In-itself') through human consciousness ('For-itself') is what constitutes the very meaning of existence and the world, inasmuch as the process of internal negation within human consciousness transmutes meaningless matter into meaningful content for consciousness.

This internal negation, or "nothingness", which inheres in human consciousness, serves as the foundation for a fundamental ontological freedom in human existence, since human existence is neither fixed nor predetermined from the outset by any being beyond our "human reality" (Sartre 2003:p. 42). This nothingness, which "lies coiled in the heart of being, like a worm" (Sartre 2003: p. 45), constitutes our freedom insofar as our mutable being is never wholly what it is since it is constantly confronted by an internal negation of its being. Moreover, and by the same measure, this internal negation of our being-for-itself leads humanity evermore beyond our immediate existence, guided by the desire to be more than we ever are at present. Unlike the non-conscious "In-itself", whose being implies a plenitude and a wholeness, the conscious human "For-itself" is an incomplete "lack", constantly haunted by its internal nothingness. The For-itself is therefore a "detotalized totality" (Sartre 2003: p. 203), obstinately questioning the nature and meaning of its existence ad infinitum et ad nauseam..$^{5}$ It is precisely this underlying, unappeasable nothingness at the heart of our human existence which precipitates an implacable desire for meaning as well as a fundamental ontological freedom that serves as a possible means-to-meaning.

On Sartre's radical account of human freedom, human beings are fundamentally free to determine both the nature and the meaning of their being for themselves owing to the nothingness that inheres and haunts the being of humankind. This message of radical freedom is embodied succinctly in Sartre's axiomatic adage that "existence precedes essence" (Sartre 2003:460),6 implying that neither the essence of human consciousness nor its existential meaning could in any way be preordained prior to the 'upsurge' of the For-itself into its existence. Significantly, it follows as a corollary of our ontological constitution that human beings have in actuality always been radically free to determine the meaning of their being for themselves. However, while humanity's fundamental freedom precludes any predetermined existential essence or meaning, it also entails a fervent human desire for meaning that is forever

${ }^{5}$ Ad nauseam insofar as Sartre's well-known novel Nausea (1938) is an account of how the inherent nature of reality, stripped of the ascriptions of meaning given through human consciousness, inspires a feeling of existential nausea. ${ }^{6}$ See also: Sartre 2007: p. 20. 
frustrated by the nothingness or "lack" which perpetually plagues human consciousness. That is, humanity lacks the absolute guarantee of a meaningful existence; both internally, owing to the constant negation which haunts our conscious ascription of meaning to existence, and externally, owing to the demise of traditional transcendent qualifications of meaning. Our ontological constitution, as sketched by Sartre, is therefore a double-edged sword of the worst variety: humanity is driven in its very being qua nothingness towards meaning, yet will never satisfactorily accede to a meaning which will fully assuage the insatiability of our desires.

Sartre further argues, rather controversially, that this unappeasable human desire for meaning directs us towards an absolutely unattainable mode of being qua "in-itself-for-itself": a being that is self-unified, self-constituted in its freedom, and replete in its being. That is, human existence, on Sartre's extreme existentialist view, quite literally entails an interminably frustrated pursuit towards Godliness; a fallible human striving which is as fruitless as it is futile. Human existence is thus a condemnation to a form of ontological freedom which, in a morbid cosmic irony, constitutes the contingent possibility of existential meaning through individual human consciousness, while simultaneously ensuring the impossibility of its absolute guarantee. For this latter reason, Sartre (2003: p. 636) concludes Being and Nothingness in a tone resonant with a residual despair: "Man is a useless passion". Yet, what may be salvaged from Sartre's account of existential meaning is the fact that human individuals do, in fact, have a means-tomeaning at their disposal, rooted in the indissoluble fundamental ontological freedom residing at the heart of each human individual. Despite the seeming futility of our desire for the absolute meaning that only a God could fashion, Sartrean existentialism argues most emphatically that human consciousness is the immanent seat of the only actual means-to-meaning in existence.

Sartre thus deliberately uproots the seat of existential meaning from its former supernal stronghold in the transcendent, and supplants it with the vitality of individual human freedom. This may appear to be the obvious counter position once transcendental qualification for existential meaning has been exhausted with the demise of religious faith concomitant with the rise of secularism. Yet, this position, though undoubtedly apposite for its time, is being rendered increasingly untenable in light of contemporary thought following in the wake of poststructuralist conceptions of meaning. Specifically, the work of contemporary philosopher Jean-Luc Nancy might be employed in such a manner as to reveal the potential pitfalls of Sartre's existentialist account of meaning, and provide a possible new means-to-meaning that has more immediate bearing on human existence in the contemporary world. 


\section{Nancy contra Sartre}

"This is how contemporary humanism defines itself: as the self-presentation of the will to meaning, or more exactly, as the self-presentation of the meaning of the will to meaning. That which governs the process and project of signification is the following: "man" signifies this project - and this project signifies man."

- Jean-Luc Nancy (1997a:24)

The contemporary philosophy of Jean-Luc Nancy draws discernible influence from the poststructuralist $^{7}$ project of deconstruction made famous by Jacques Derrida. ${ }^{8}$ Nancy acknowledges the poststructuralist critique that has transpired in the period of Western thought since Sartre's ontology first emerged, and actively engages in furthering such critique, with the aim of gaining a greater understanding of contemporary human existence and its possible meaning(s). Akin to Derrida's poststructuralist critique, Nancy redefines meaning in such a manner as to look askance at previously upheld human orders of signification. ${ }^{9}$ In what follows, the poststructuralist elements of Nancy's thought, underpinned by Derridean deconstruction, will be highlighted and applied to Sartre's existentialist philosophy, with the intention of revealing the potential pitfalls of Sartrean thought on the question of existential meaning, and thereby indicating the need for its contemporary (re)conceptualization.

Nancy (re)visits the question of existential meaning by identifying the problematic nature of any conception of meaning predicated on what Derrida famously calls a "metaphysics of presence" (Derrida 2001: p. 354). Derrida posits that a metaphysics of presence underpins all Western philosophical thought since Plato, inasmuch as it subscribes either deliberately or inadvertently to an underlying binary logic which suggests that meaning has a "fixed origin" (archē), and/or destination (telos); and following this logic, it has been the purposive pursuit of philosophers to locate the "point of presence" of meaning in reality (Derrida 2001: pp. 352-353).10 Following Derrida, Nancy asserts that a conceptualization of meaning based on the attempt to situate its presence is, in fact, the very modus operandi of Western metaphysics in its entirety, which "suffices to make the whole of philosophy into a general enterprise of signification and presentation" (Nancy 1997a: p. 23). In The Gravity of Thought, Nancy (1997a: p. 10) draws an important distinction between signification and meaning: "signification is located meaning, while meaning resides only in the coming of a possible signification." Nancy (1997a: p. 22) adds

\footnotetext{
7 Poststructuralism refers to a particular variety of postmodern thought which seeks to disrupt the presence of meaning by revealing that meaning is constituted by a play of difference(s), and not secured in a static source.

${ }^{8}$ For a succinct account of Nancy's principal influences, see Hutchens 2005: pp. 24-32.

9 Specifically, religious orders of signification, as may be found in Dis-Enclosure: The Deconstruction of Christianity (2008) as well as socio-political orders of signification, as may be found in Retreating the Political (1996).

10 Nancy (1997b: pp. 16-21) highlights the more recent "point of presence" established in human consciousness through the discourse of phenomenology, as well as in humanity itself through the discourse of humanism (Nancy 1997a: pp. 24-25). Both these points are applicable to Sartrean thought, which is phenomenological and humanist.
} 
to this that "[m]eaning in general is meaning understood as signification" where signification here refers to "the presentation of meaning." This argument suggests that meaning in all its forms is typically or traditionally thought to be that which is present or presentable by means of an order of signification consisting of a signifier in referential relation to a signified. In Nancy's terms, this is meaning qua signified presence, or simply meaning qua signification.

Contrary to the logic embodied in meaning qua signification, Nancy's contemporary thought on meaning sets out to undermine the operations of such logic by "deconstructing" the ostensible presence of meaning, thereby destabilising its fixed presence, and revealing a multitude of previously effaced meaning(s). Nancy subscribes to Derrida's poststructuralist view that meaning is made manifest by means of its internal "différance": a Derridean neologism which indicates that the presence of meaning is perpetually deferred and established in the "play" of difference(s) between signifiers in an infinite chain of signification (Derrida 2001: p. 369).11 Meaning, whether linguistic, logical, or existential, cannot be said to subsist in and of itself; it is the (by-)product of différance in that its source or origin is perpetually deferred and its presence or presentation is revealed only through relational difference(s) between signifiers.

Following this logic of différance, the presence of existential meaning qua signification, rather than being immediately accessible to humanity, is interminably displaced beyond appropriation. On Nancy's view - a view which I wish here to affirm - existential meaning qua signification is nothing more than a "fantasy" (Nancy 1997a: p. 29); an illusory and ever-elusive mirage of meaning. Signification represents the meaning of a future which is never fully present, despite its promise and its purchase upon our thinking. Ironically, meaning qua signified presence is therefore never in fact present as such, but ceaselessly suspended, (with)held aloft and afar, in or as the beyond of our being:

"The meaning that thought invokes is always elsewhere, always displaced, always on the move; or more exactly, the presence of meaning immediately opens the indefinite perspective of its projection into an elsewhere" (Nancy 1997a: p. 30).

Applying the above critical poststructuralist approach to Sartrean thought reveals that Sartre's phenomenological ontology and existentialism in Being and Nothingness renders itself complicit in an outmoded metaphysics of presence by displacing the point of presence from the transcendent domain of supernal signifieds to the immanent domain of human consciousness. ${ }^{12}$ A conception of meaning as strictly immanent is no less guilty of subscribing to a metaphysics of presence insofar as it still seeks to locate, establish, and pinpoint the presence or source of

\footnotetext{
11 For a full explanation of différance, see Derrida (2004).

12 Both Derrida (2001:353) and Nancy (1997b: p. 17) identify that the discourse of phenomenology, to which Sartre subscribes, involves (re)situating the source of signification in human consciousness.
} 
signification, albeit in a more immediate location, viz. the freely-constituted meaning of individual human consciousness. Nancy's critical engagement with existential meaning qua signification allows one to understand that Sartre's existentialist attempt at meaning ultimately succumbs to the same elusive meaning "present-at-a-distance" that haunts all signification (Nancy 1997a: pp. 37-42). Through Sartre's existentialist conception, meaning has changed merely its point of presence, but the underlying problematic logic of meaning qua signified presentation remains unchallenged and unchanged. As a result, existential meaning is still implicitly pursued by Sartre as if it should manifest as such or in itself, but that such a manifestation of meaning ultimately remains perpetually absent, to humanity's undying despair.

If, as Sartre contends, human consciousness is itself an implacable nothingness or "lack", then its desire for meaning remains interminably unsated, and any manifest presence of meaning is infinitely deferred through a perpetual process of internal negation in human consciousness. This is to say that the ostensible source of all meaning, viz. human consciousness, is the same element which precludes meaning's complete manifestation. For, in Sartre's view, humanity is "a useless passion" in that it will forever seek out an ultimate meaning that could never find fruition in a finite world. According to Nancy (1997a: p. 32), such desire for complete meaning is indeed "the law of signification", and ultimately, human desire is doomed to failure because it immediately demands that which is forever deferred. Thus, in Sartrean thought:

"desire is at work with its own power, which is the power of the negative: the division of the subject from itself, the ensuing revelation that its truth, value, and end lie elsewhere, though it is itself this elsewhere, one that consequently never ceases to reopen in the subject a gaping hole full of fever and disorder - the fever and disorder of an identification that is condemned in advance to an infinite exhaustion" (Nancy 1997a: p. 33).

Moreover, Sartre's humanist conception of meaning in Existentialism is a Humanism possibly overextends human beings beyond their fallible and finite nature, for it asks human individuals to embody and evince a creative ardour akin to that of God, and thereby overinflates our responsibilities as meaning-makers by assigning the entire burden of meaning to the shoulders of human individuals. If we, as individuals, then miscarry this weighty assignment to render existence meaningful in and of ourselves, then we might look upon ourselves as abysmal creatures plunged once again into the infinite night of nihilism. The inevitably of such a grim eventuality is all but guaranteed by a subscription to a metaphysics of presence, as Sartre's existentialism argues that humanity will perpetually desire absolute existential meaning to be made manifest from our fallible human consciousness. The irony of Sartre's existentialist conception of meaning should thus not be overlooked: for resituating the source of meaning in 
human consciousness may yet precipitate an even deeper meaninglessness in human existence if, or indeed when, meaning does not manifest itself fully in individual consciousness alone.

Furthermore, if the source of existential meaning is simply transferred into the hands of human individuals, then it is delivered over to all the implications of a rampant relativism and a potentially atomistic subjectivism, which may yet foster further discord and discontent between competing conceptions of existential meaning, possibly even precluding a shared sense of existence between human beings. A study of human history demonstrates the potential negative implications of discord between competing conceptions of existential meaning, ranging from religious crusades to genocidal atrocities committed in the name of more secular ideologies. Therefore, with the aim of diminishing the prevalence and extent of such troubling human tragedies, and further fostering a more fruitful and hopeful human future, one might argue that it is incumbent on humanity henceforth to rethink existential meaning in such a manner as to cultivate a pluralism of meaning(s), with human existence(s) participating in the world as a shared space of sense.

\section{A Contemporary Sense of Existentialism}

"Being itself is given to us as meaning. Being does not have meaning. Being itself... is meaning that is, in turn, its own circulation - and we are this circulation. There is no meaning if meaning is not shared, and not because there would be an ultimate or first signification that all beings have in common, but because meaning is itself the sharing of Being."

- Jean-Luc Nancy (2000: p. 2)

Since the mid-twentieth century, when Sartre first sought to fathom the depths and meaning(s) of human existence, the face of the world in its entirety has changed considerably. The contemporary world has become more interconnected and interdependent than ever before in human history, ${ }^{13}$ and our continued human existence in this world of manifold meaning(s) is beginning to demand a relevant contemporary philosophical account of human existence that can accommodate and affirm difference(s) of existential meaning(s), such that humanity might mitigate the problematic tensions and conflicts that often arise on the grounds of seemingly irreconcilable conceptions of existential meaning. Nancy (1997a: p. 10) paves a path for precisely such a (re)thinking of human existence and its possible meaning(s) by posing a pertinent philosophical question: "What is one asking, henceforth, when one asks for meaning?"

13 This is due to phenomena such as globalisation, the expansiveness of technology (especially the Internet, mainstream media, \& social media), and contemporary issues such as environmentalism (especially climate change) and even the possibility of unprecedented human warfare, all of which affect the world and humanity in its entirety. 
In a manner akin to Nietzsche and the early Heidegger, from whom Nancy draws appreciable influence, ${ }^{14}$ Nancy recognises a world bereft of transcendent significance following in the wake of the notorious Nietzschean "death of God",15 and seeks furthermore to fathom the nature and meaning of human existence in this world, to which humanity is henceforth abandoned without recourse to any qualification of meaning beyond its bounds. Nancy's background in existentialism, ontology, and poststructuralism, in conjunction with his astute contemporary philosophical insights into the contemporary world and human existence, renders him a most apposite candidate for a contemporary (re)conceptualization of existentialism. The argument which follows provides a brief account of Nancy's (re)conceptualization of meaning qua sense, and sketches a possible groundwork for a contemporary sense of existentialism, including a tentative indication of some of the central tenets which might feature in such a future account.

In The Gravity of Thought, Nancy (1997a: pp. 43-45) suggests that the deconstruction of Western metaphysics has revealed the exhaustion of meaning qua signification, leaving humanity ostensibly bereft of existential meaning altogether. On this basis, Nancy envisages a novel conception of existential meaning that goes beyond existential meaning qua signification by moving towards a philosophy of existential meaning qua "sense". In The Sense of the World, Nancy (1997b: pp. 4-5) commences with the premise that the contemporary world no longer possesses any signified sense to call upon, but has itself become its own sense. Nancy avers that the world is sense inasmuch as our worldly existence today offers only itself as a space of sense; sans transcendent signification, sense circulates along the very confines of this world, here and now, and nowhere else. By (re)thinking existential meaning in this way, Nancy is addressing that which demands to be (re)thought under contemporary human conditions: a sense of existence that is neither strictly transcendent nor immanent, but "trans-immanent" (Nancy 1997b: p. 55) insofar as its space of circulation is always already here in this world (immanent), across (trans) all beings that reside within the space of its worldly circulation.

Nancy (2000: pp. 1-3) argues that existential meaning entails the sharing [partage] of Being between beings because existence entails a primordial "being-with" other beings [Mitsein],16 or what Nancy (2000) designates as "being singular plural". ${ }^{17}$ Humanity is singular plural in the sense that human singularity always already implies a comparative relation of difference between beings: to be a unique individual is to be different from another being with whom one shares a world, and this difference already implicates each singular being in the pluralism of being-with. Owing to the singular plural nature of human existence, existential meaning is

14 Though not himself an existentialist as such, Nancy's philosophy evinces discernible existentialist themes, such as abandonment, responsibility, and most germane to the study at hand, the meaning of human existence.

15 In The Gay Science, §125 Nietzsche infamously writes that "God is dead. God remains dead. And we have killed him."

${ }^{16}$ A point which Nancy draws from Heidegger's fundamental ontology in Being and Time (\$§26-27).

17 This is also the title of Nancy's 2000 work Being Singular Plural. 
similarly never an isolated affair, but entails an original relation of difference and plurality. Existential meaning qua sense entails an exposure, engagement, or encounter with an otherness of existential meaning which is derived from a play of difference(s) between beings sharing a world. Nancy (1997b: pp. 34-36) asserts, following in Derrida's poststructuralist logic, that this is the very play of différance that constitutes all meaning, including existential meaning qua sense, which is constantly made manifest on the basis of difference(s); brought about by means of a deferred immanence across or between beings - a trans-immanence. For Nancy, sense is always already circulating between beings; sense is a being-between (être-entre) for it entails a mediation of this mundus as a shared space(-ing) of sense.

In Nancy's view, humanity is always already immersed and implicated in the world and its circulation of sense which "preexists signification and exceeds it" (Nancy 1997a: p. 59). Sense entails "existence qua liability to meaning" (Nancy 1997b: p. 157); an original ontological orientation to the possibility that existence and the world can make sense. This original orientation towards the world as a space of sense facilitates all human (inter)action, communication, and thought, since when we (inter)act, speak, or think, we are always already swept up in the world and its possibilities of sense(s). Contra existential meaning qua signification, sense elides its inception and eludes its closure, since it is between beings, and thus can never be sourced or fixed for all time - neither in transcendent meaning, nor in individual immanence. Sense is always already becoming manifest without manifesting itself in and of itself, which is to say that sense is only present between us, but never at any fixed or isolatable point of presence: "meaning takes place between us and not between signifier, signified, and referent" (Nancy 1997a: p. 57). Attempting to arrest sense in a static order of signification constitutes a suspension of the worldly circulation of sense, unnecessarily closing existence to its myriad possible meaning(s) by selectively securing some particular sense of the world in an ossified absolute. Such a move is problematic inasmuch as it denies the singular plural nature of our worldly human existence. By making an absolute of singular sense, meaning is made to bypass the plural, which, for Nancy (2000), cannot be bypassed, for the plural is an intrinsic aspect of our ontological constitution as singular plural beings.

Nancy (1997b: p. 74) therefore calls upon contemporary humanity to adopt an existential disposition of exposure to the world, its inhabitants, and its myriad meaning(s). Such an existential exposure requires an implicit recognition of this world as sense, further implying a responsiveness to the world as it is, and a responsibility to the world as it may yet be. Humanity must therefore not anticipate the manifestation of meaning in its pure signified presence, but must participate in the meaning qua sense of the world which is always already circulating 
through singular plural passages of presence ${ }^{18}$ in the form of human (inter)actions, thoughts, and worldly engagements and (co-)operations. This open participation in the sense of the world suggests, for Nancy (2000: p. 2), that "we are meaning" through an existential exposure to human existence(s) in all its worldly plurality.

Continuing along this line of argumentation, Nancy (1997b:78) conceptualises "the infinity of finite senses", or "infinite finitude",19 which stems from Nancy's view that sense "is nothing other than 'the world tout court,' this world whose 'here' is not opposed to a [transcendent] 'there' but articulates all possible beings-there." The possibilities of existential meaning qua sense are thus rooted in humanity's immediate worldly finitude, but are infinite in number, owing to the plurality of worldly beings and the innumerable permutations and combinations of responses to existence through different human (inter)action(s), thought(s), and worldly engagement(s). Infinite finitude also implies that sense is inexhaustible in its scope since existence maintains the perpetual possibility of surprise: the unforeseen arrival or event of sense (Nancy 1997b: p. 128). ${ }^{20}$ The trans-immanence of sense means that sense is here and now, circulating between finite beings sharing existence within a finite world, while simultaneously retaining its infinite inexhaustibility through the possibilities opened up by an unbounded array of finite meanings. Nancy (1997b:35) articulates this idea succinctly as follows:

"The coming [of sense] is infinite: it does not get finished with coming; it is finite: it is offered up in the instant."

An infinite plurality of finite meaning(s) further implies that meaning qua sense does not manifest itself in any absolute sense, nor could meaning be absolutely absent from existence. Nancy's conception of meaning qua sense thus undermines a nihilistic conception of human existence, since even the discourse on meaninglessness implies a participation in meaning qua sense insofar as

"denying the presence of meaning affirms that one knows what meaning would be, were it there, and keeps the mastery and truth of meaning in place" (Nancy 2000: p. 1).

For Nancy (1997b: pp. 79-80), human existence can only be deemed to be sans sense if it is judged against a superimposed measure of what existence ideally ought to be, which runs counter to a responsible human orientation towards the world as an infinite reserve of finite sense(s). This is not to say that humanity should not seek to improve its existential condition, but requires that humanity recognise the worldly nature of its condition, and remain forever exposed to the trans-immanent circulation of sense throughout this world here and now. In this

\footnotetext{
18 Nancy 2000: p. 5 refers to "the crossing-through [passages] of presence."

${ }^{19}$ For a more extensive description of this term, see: Nancy 1997b: pp. 29-33.

20 See also Nancy 1997b: p. 147. Nancy (1997a: p. 70) describes this surprise of existence as a "shock of meaning".
} 
way, Nancy circumvents the human demand for absolute meaning, and simultaneously subverts the possibility of utter meaninglessness by affirming the fact that human existence finds itself thrown into an uncertain, yet inexhaustible space of sense between the antipodes of the absolute and the abyss.

Following Nancy's abovementioned insights on meaning qua sense and human existence as singular plural, a number of tentative tenets for a contemporary sense of existentialism might be put forward. Firstly, sense precedes existence inasmuch as sense and world are coextensive, which is to say that human existence always already entails a participation in the transimmanent worldly circulation of sense. To say that sense precedes existence is to append to Sartre's notion that "existence precedes essence" the further qualification that the world as sense antecedes all individual existential projects of meaning qua signification. Secondly, the world is a shared space of sense, calling for an existential disposition of responsible openness or exposure to an otherness of existential meaning, which is to understand existential meaning as trans-immanent rather than transcendent or immanent, contingent rather than absolute, and worldly rather than otherworldly. Thirdly, human existence is singular plural rather than individualist, with the concomitant corollary that this world plays host to the trans-immanent circulation of an infinite finitude of sense(s) made manifest on the grounds of an original ontological relation of difference between beings. Finally, a contemporary sense of existentialism should avoid the reduction(ism) of an infinity of finite sense(s) to the meaning of life, and argue instead for the manifold meaning(s) to(wards) life. In this way, a contemporary sense of existentialism would acknowledge and affirm the pluralism of our contemporary world, and offer a possible means-to-meaning that speaks to its demands.

\section{Conclusion}

While one might justifiably assert that Sartre offers an account of existentialism that is both apposite and astute for its time, its formulation of existential meaning is rendered increasingly problematic in light of the poststructuralist critique of Western philosophy following in its wake. By deconstructing Sartre's account of existential meaning, and thereby revealing a vestigial metaphysics of presence operating within its immanent individualism, the possibility and demand for a contemporary (re)conceptualization of existentialism is made manifest. Contrary to Sartre, contemporary existentialism might assert that humankind is not in fact "a useless passion" striving in a most futile fashion towards the ideal of some grandiose meaning worthy of the glory of a God. Rather, the human movement towards existence as meaningful presupposes a participation in, and an exposure to, this world as sense, and it is this orientation towards the world as sense which allows us to understand that no human passion could ever be deemed absolutely meaningful nor utterly meaningless. By opening up the possibility of 
meaning(s) beyond the parameters of traditional Western philosophy, Nancy allows contemporary humanity to face the fact that only our shared contemporary existence in this interconnected and pluralistic world summons us to sense, and it is this summons to sense which requires humanity to take responsibility for the myriad possible meaning(s) of existence in this shared world here and now. 


\section{References}

Blackburn, S. 2008. The Oxford Dictionary of Philosophy. Oxford: Oxford University Press.

Derrida, J. (1967) 2001. Writing and Difference. Translated by Alan Bass. London \& New York: Routledge.

Derrida, J. 2004. “Différance." In: Julie Rivkin \& Michael Ryan (eds). Literary Theory: An Anthology. 2nd ed. Malden, MA: Blackwell, pp. 278-299.

Heidegger, M. (1927) 1962. Being and Time. Translated by John Macquarrie \& Edward Robinson. New York: Harper \& Row.

Hutchens, B.C. 2005. Jean-Luc Nancy and the Future of Philosophy. Bucks, United Kingdom: Acumen.

Nancy, J-L. (1993) 1997a. The Gravity of Thought. Translated by François Raffoul \& Gregory Recco. New York: Humanity Books.

Nancy, J-L. (1993) 1997b. The Sense of the World. Translated by Jeffrey S. Librett. Minneapolis \& London: University of Minnesota Press.

Nancy, J-L. (1996) 2000. Being Singular Plural. Translated by Robert D. Richardson \& Anne E. O’Byrne. Stanford: Stanford University Press.

Nietzsche, F. (1887) 1974. The Gay Science. Translated by Walter Kaufmann. New York: Vintage. Sartre, J-P. (1938) 1965. Nausea. Translated by Robert Baldick. London \& New York: Penguin.

Sartre, J-P. (1943) 2003. Being and Nothingness. Translated by Hazel E. Barnes. New York \& London: Routledge.

Sartre, J-P. (1946) 2007. Existentialism is a Humanism. Translated by Carol Macomber. New Haven \& London: Yale University Press. 